\title{
Analisis kualitas fisika kimia air di areal budidaya ikan Danau Tondano Provinsi Sulawesi Utara
}

(Analysis of physical-chemical quality of waters at aquaculture area in Lake Tondano, North Sulawesi Province)

Richard Maniagasi, Sipriana S. Tumembouw, Yoppy Mundeng.

\begin{abstract}
The objective of this research was to analyse the physical-chemical quality of waters at aquaculture area in Lake Tondano North Sulawesi. Water quality was measured in situ and in laboratotium. In situ measurement included temperature, $\mathrm{pH}$, and turbidity, while in laboratory, water quality measured included dissolved oxygen, nitrogen, phosphate. It was found that water temperature ranged from $25-27{ }^{\circ} \mathrm{C}$, turbidity $0.20-4,0 \mathrm{~m}$, and dissolved oxygen 5 - $8 \mathrm{mg} / \mathrm{L}, 5$ - 9, Nitrogen 0,0334 - 0,0697 mg/ L, phosphate 0 - 0,0219 mg/ L. It was concluded that water quality around Paleloan Village was appropriate for aquaculture activity.
\end{abstract}

Keywords: water quality, aquaculture, Paleloan Village

\section{PENDAHULUAN}

Pengendalian kondisi lingkungan budidaya agar tetap stabil dan optimal bagi organisme perairan termasuk ikan sebagai hewan budidaya menjadi sangat perlu dilakukan. Sehingga secara khusus pengolahan dan air sebagai tempat budidaya perlu dilakukan.

Air yang digunakan untuk keperluan budidaya perikanan tidak sekedar air (H2O), karena air mengandung banyak ion. Ion-ion unsur yang kemudian menentukan apakah lingkungan tersebut cocok untuk kegiatan budidaya.

Jadi kualitas air yang baik adalah air yang cocok untuk kegiatan budidaya, dimana jenis komoditas bisa hidup dan tumbuh dengan normal. Ketersediaan air yang baik sangat penting di dalam budidaya perikanan, air yang bagus memiliki karakteristik lingkungan spesifik untuk mikroorganisme yang dibudidayakan.

Kualitas air tidak terbatas pada karakteristik air, tetapi lebih dinamis yang merupakan hasil dari proses faktor-faktor lingkungan dan proses biologi. Oleh karena itu untuk menghasilkan kualitas air yang baik maka perlu ada kegiatan monitoring yang rutin. Kebutuhan kualitas air tiap spesies berbeda bahkan dalam setiap tahap perubahan dalam satu siklus hidup dalam satu spesies. Sehingga kondisi air media harus diuji terlebih dahulu sebelum membuat keputusan dan mengambil tindakan selanutnya. Oleh karena itu setiap pembudidayaan harus memahami hal-hal penting yang perlu mendapat perhatian ketika akan dan sedang melakukan budidaya.

Permintaan produk perikanan untuk memenuhi gizi manusia semakin meningkat, sementara tingat ketersediaan potensi sumber daya ikan diprediksi terus berkurang dengan peningkatankonsumsi. Salah satu cara yang bisa menjawab tuntutan kebutuhan gizi dan protein hewani adalah dengan budidaya ikan. Dalam usaha pengembangan budidaya, danau merupakan salah satu sumberdaya alam yang bisa dimanfaatkan (Zonnelved, 1991).

Danau adalah wilayah yang digenangi badan air sepanjang tahun yang terbentuk 
secara alami karena gerakan kulit bumi sehingga bentuk dan ukurannya bervariasi. Danau saat ini bisa digunakan sebagai tempat rekreasi, sumber pembangkit tenaga listrik (PLTA), sumber utama pengairan bagi usaha pertanian dan juga sebagai tempat pembudidaya ikan (Walandow,1997).

Masyarakat di sekitar Danau Tondano memanfaatkan air danau sebagai tempat usaha budidaya ikan dengan sistem keramba jaring tancap dan sistem keramba jaring apung. Menurut Nastiti $d k k$ (2001), perkembangan unit keramba jaring apung dan keramba jaring tancap pada areal budidaya yang kurang terkendali menimbulkan dampak negatif terhadap linkungan perairan. Masalah yang timbul adalah pencemaran lingkungan yang disebabkan oleh berbagai kegiatan disekitar perairan maupun dari usaha budidaya itu sendiri. Dari usaha budidaya contohnya pakan yang diberikan tidak dikonsumsi dengan baik oleh ikan. Sisa pakan yang tidak habis dimakan akan mengendap di dasar perairan kemudian terjadi proses dekomposisi oleh mikroorganisme. Dalam proses dekomposisi dibutuhkan oksigen dalam jumlah yang besar. Bila suplai oksigen tidak cukup, kondisi anaerob pada dasar danau tidak dapat dihindari. Kondisi anaerob ini bisa menghasilkan subtansisubtansi beracun seperti amoniak, nitrit dan sulfur. Secara tidak langsung sudah merubah sifat-sifat fisik dan kimia dari perairan. Lingkungan hidup yang tidak memenuhi syarat akan berakibat buruk bagi ikan yang dibudidayakan misalnya kematian ikan dan adanya penyakit yang menyerang ikan peliharaan. Tentunya hal ini sangat berpengaruh buruk bagi petani ikan.

Dalam usaha budidaya ikan, sangat penting mempelajari kondisi kualitas air karena parameter kualitas air merupakan faktor pembatas terhadap jenis biota air yang dibudidayakan di suatu perairan. Melihat begitu pentingnya peranan kualitas air maka perlu dilakukan penelitian terhadap parameter kualitas air sehingga dijadikan indikator kelayakan suatu perairan untuk dijadikan tempat usaha budidaya ikan.

\section{BAHAN DAN METODE}

Penelitian ini menggunakan dua metode pengukuran yaitu pengukuran sampel di lapangan (in situ) dan analisis sampel di laboratorium. Parameter kualitas air yang diukur langsung di lapangan meliputi suhu, derajat keasaman (pH),dan kecerahan. Parameter kualitas air yang dianalisis di labiratorium meliputi oksigen terlarut (DO), kekeruhan, nitrogen (N2) dan fosfat (PO4). Oksigen terlarut (DO) dianalisis di Laboratorium Badan Penelitian dan Pengembangan Industri Balai Riset dan Standarisasi Industri Manado. Untuk kekeruhan, nitrogen () dan fosfat (PO4) dianalisis Dinas Kesehatan Propinsi SULUT.

\section{HASIL DAN PEMBAHASAN Suhu}

Berdasarkan hasil pengukuran dilapangan diketahui bahwa keberadaan suhu air danau cukup bervariasi yaitu sekitar 25 hingga $28{ }^{\circ} \mathrm{C}$. Pada dasarnya bahwa dengan adanya variasi suhu yang cukup besar dapat memberikan dampak atau pengaruh yang cukup besar pula terhadap berbagai aktifitas metabolisme dari organisme yang mendiami suatu perairan. Menurut Boyd dalam Karu (2000) bahwa variasi suhu suhu dipengaruhi oleh beberapa faktor yaitu antara lain tingkat intensitas cahaya yang tiba di permukaan perairan, keadaan cuaca, awan dan proses pengadukan.

Hasil pengukuran suhu pada stasiun pengamatan I, II dan III dapat ditampilkan dalam bentuk histogram seperti yang tampak pada Gambar 1. 


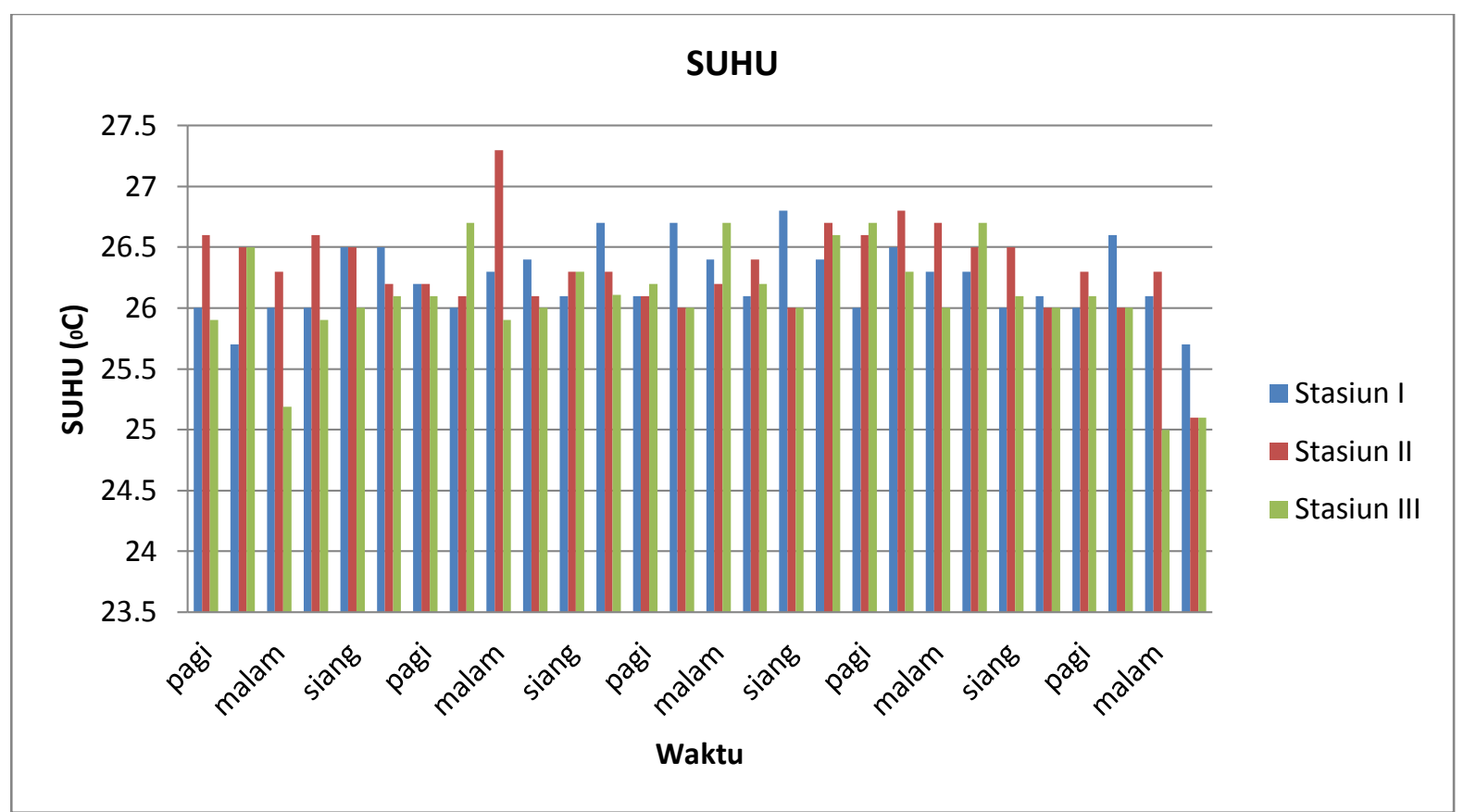

Gambar 1. Histogram suhu pada tiga stasiun pengamatan berbeda

Secara umum diketahui suhu yang diperoleh pada hasil pengamatan terhadap 3 stasiun yang berbeda sekitar suhu $26^{\circ} \mathrm{C}$, walaupun dijumpai pula pada saat tertentu suhu terendah sekitar $25^{\circ} \mathrm{C}$ dan suhu tertinggi yakni pada siang hari dapat mencapai sekitar $27^{\circ} \mathrm{C}$. Tinggi rendahnya suhu suatu perairan sangat ditentukan oleh beberapa faktor antara lain ketinggian suatu daerah, curah hujan yang tinggi, dan intensitas cahaya matahari yang menembus suatu perairan.

Menurut Anonimous (2001a), air yang dangkal dan memiliki daya tembus cahaya matahari yang tinggi dapat meningkatkan suhu perairan. Dengan demikian berarti suhu merupakan salah satu faktor yang mempengaruhi kualitas air.

Pada dasarnya suhu sangat berpengaruh terhadap kehidupan dan pertumbuhan ikan. Menurut Kordi dan Tancung (2005), suhu mempengaruhi aktivitas metabolisme organisme, oleh karena penyebaran organisme di perairan tawar dibatasi oleh suhu perairan tersebut.

Memperhatikan range suhu yang diperoleh pada tiga stasiun pengamatan yang berbeda di desa Paleloan seperti sangat baik untuk menunjang usaha budidaya perikanan air tawar. Hal ini selaras dengan pernyataan dalam Kordi (2010), bahwa suhu yang cocok untuk kegiatan budidaya biota air antara 23 hingga $32{ }^{\circ} \mathrm{C}$. 


\section{Kecerahan (m)}

Berdasarkan hasil pengukuran dilapangan diketahui bahwa keberadaan nilai kecerahan air danau khususnya di desa Paleloan cukup bervariasi yaitu sekitar 0,20 hingga 4,0 m. mengenai hasil pengukuran kecerahan pada stasiun pengamatan I, II dan III dapat ditampilkan dalam bentuk histogram seperti yang tampak pada Gambar 2.

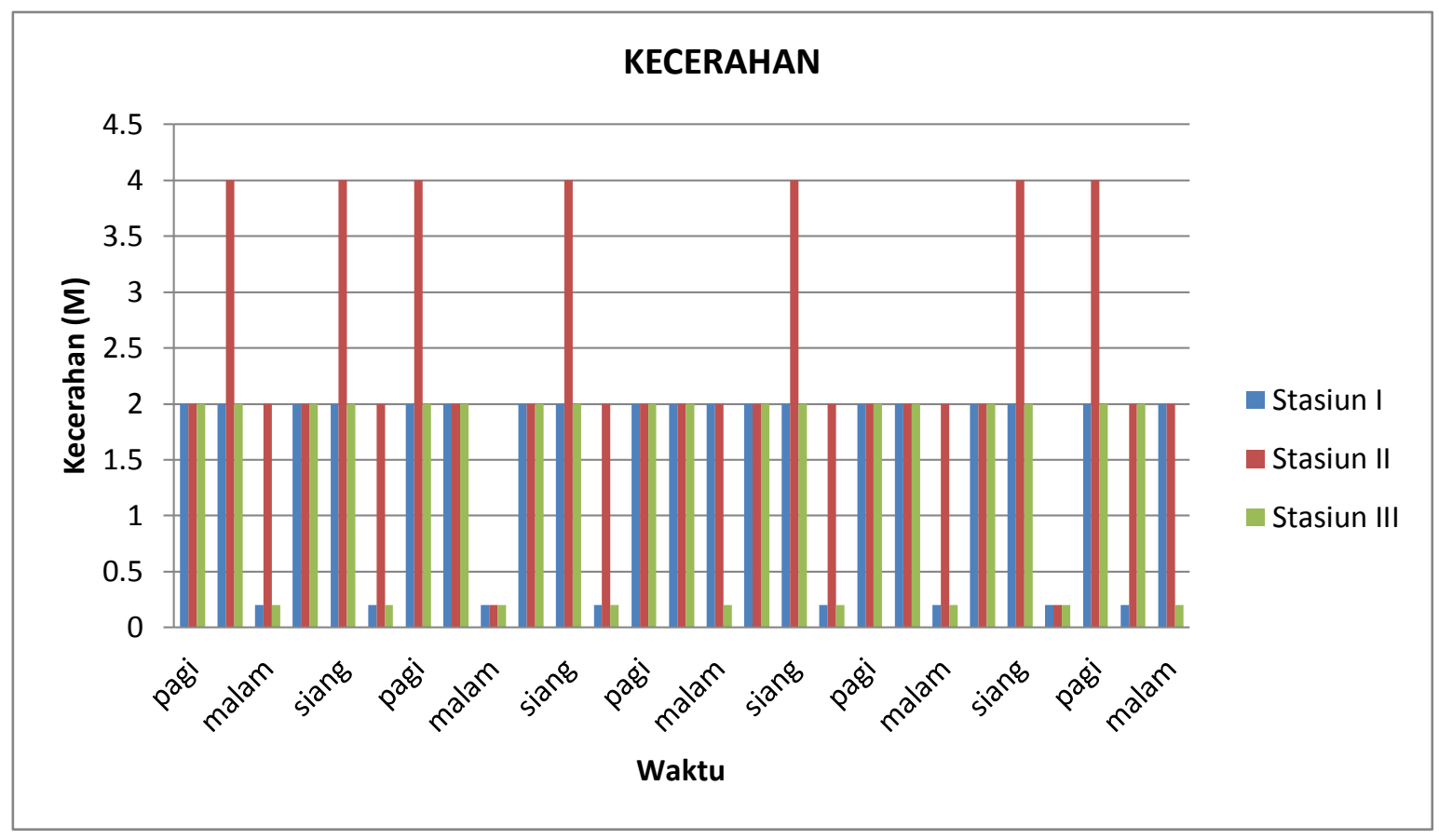

Gambar 2. Histogram kecerahan pada 3 stasiun pengamatan berbeda

Memperhatikan nilai kecerahan dari hasil pengamatan di desa Paleloan untuk tiga stasiun pengamatan yang berbeda diperoleh nilai terendah sekitar $1 / 5 \mathrm{~m}$ dan terjauh sekitar $4 \mathrm{~m}$. Pada umumnya diketahui nilai kecerahan pada pagi hari dan siang hari didominasi sekitar $2 \mathrm{~m}$ walaupun dijumpai pula sekitar $4 \mathrm{~m}$. Untuk malam hari nilai kecerahan dominan dipoeroleh sekitar 1/5 m. Perbedaan nilai yang cukup signifikan antara pagi hari/ siang hari dan malam hari sangat ditentukan oleh intensitas cahaya matahari yang menembus pada suatu perairan.

Menurut Kordi dan Tancung (2005), kecerahan adalah sebagian cahaya yang diteruskan ke dalam air dan dinyatakan dengan persen (\%), dari beberapa panjang gelombang di daerah spektrum yang terlibat cahaya yang melalui lapisan sekitar satu meter, jatuh agak lurus pada permukaan air. Kemampuan cahaya matahari untuk menembus sampai ke dasar perairan dipengaruhi oleh kekeruhan suatu perairan. Dengan mengetahui nilai kecerahan suatu perairan, berarti dapat mengetahui pula sampai dimana masih ada kemungkinan terjadi proses asimilasi dalam perairan. Berkaitan dengan keadaan nilai kecerahan yang diamati dapat dikatakan bahwa memiliki nilai kecerahan yang agak tinggi. Tingginya nilai kecerahan karena berada diatas nilai kecerahan $25 \mathrm{~cm}$. Menurut Kordi dan Tancung (2005), semua plankton jadi berbahaya kalau nilai kecerahan suatu perairan kurang dari $25 \mathrm{~cm}$ kedalaman piringan secchi. Kecerahan yang baik bagi usaha budidaya budidaya ikan dan biota 
lainnya berkisar $30-40 \mathrm{~cm}$. Bila kecerahan sudah mencapai kedalaman kurang dari $25 \mathrm{~cm}$, berarti akan terjadi penurunan oksigen terlarut secara dratis.

\section{Oksigen Terlarut}

Berdasarkan hasil pengukuran dilapangan diketahui bahwa keberadaan nilai oksigen terlarut pada air danau khususnya di desa Paleloan cukup bervariasi yaitu sekitar 5 hingga 8 . Hasil pengukuran oksigen terlarut pada stasiun pengamatan I, II dan III dapat ditampilkan dalam bentuk histogram seperti yang tampak pada Gambar 3.

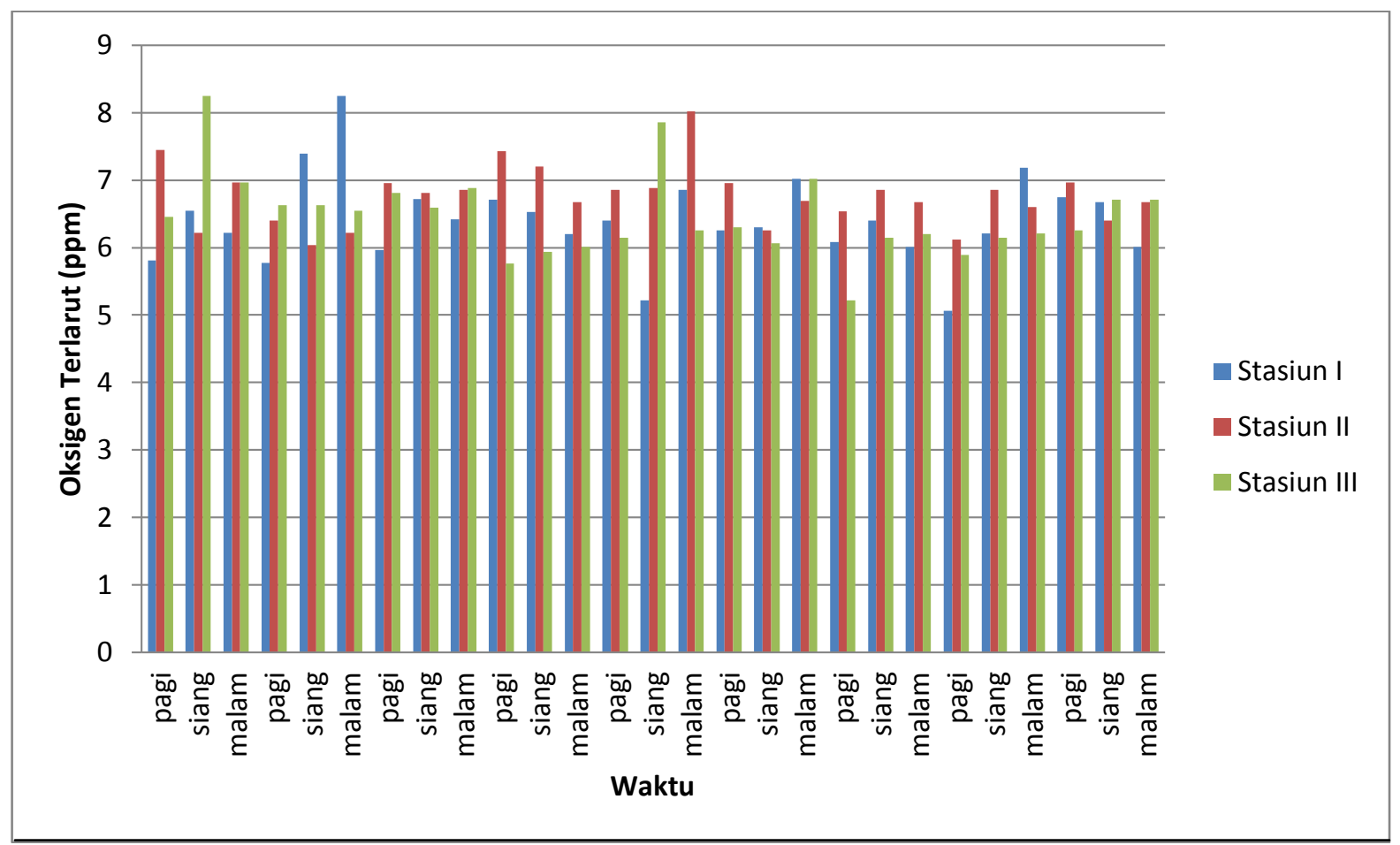

Gambar 3. Histogram oksigen terlarut pada 3 stasiun pengamatan berbeda

Memperhatikan nilai oksigen terlarut dari hasil pengamatan di desa Paleloan untuk tiga stasiun pengamatan yang berbeda diperoleh nilai terendah sekitar 5,06 dan tertinggi sekitar 8,25 ppm. Nilai oksigen terlarut terendah 5,06 merupakan hasil pengamatan pada pagi hari dan nilai oksigen terlarut tertinggi 8,25 adalah hasil pengamatan pada malam hari. Tinggi rendahnya nilai oksigen terlarut erat hubungannya dengan pergerakan air pada suatu perairan. Oksigen terlarut dalam suatu perairan merupakan faktor pembatas bagi organisme akuatik dalam melakukan aktifitas. Keadaan ini selaras pernyataan Kordi dan Tancung (2005), bahwa pada waktu pagi atau fajar, konsentrasi oksigen terlarut rendah dan semakin tinggi pada siang atau sore hari. Biota air membutuhkan oksigen guna pembakaran bahan bakaranya (makanan) untuk menghasilkan aktifitas, seperti aktifitas berenang, pertumbuhan, reptoduksi, dan sebaliknya. Oleh karena itu ketersediaan oksigen bagi biota air menentukan lingkaran aktifitasnya, konversi pakan, demikian juga laju pertumbuhan bergantung pada oksigen. Kekurangan oksigen dalam air dapat menggangu kehidupan biota air, termasuk kepesatan pertumbuhannya. Konsentrasi oksigen yang baik dalam usaha budidaya perairan 
adalah antara $5-7$ ppm (Kordi dan Tancung, 1997).

Keberadaan nilai oksigen terlarut pada tiga stasiun pengamatan di desa Paleloan memberikan gambaran bahwa keadaan ini berada pada batas range konsentrasi yang baik. Dengan kata lain usaha budidaya ikan dapat dilakukan karena ditunjang oleh nilai oksigen terlarut suatu perairan.
Berdasarkan hasil pengukuran dilapangan diketahui bahwa keberadaan nilai oksigen terlarut pada air danau khususnya di desa Paleloan cukup bervariasi yaitu sekitar 5 hingga 9. Hasil pengukuran oksigen terlarut pada stasiun pengamatan I, II dan III dapat ditampilkan dalam bentuk histogram seperti yang tampak pada Gambar 3.

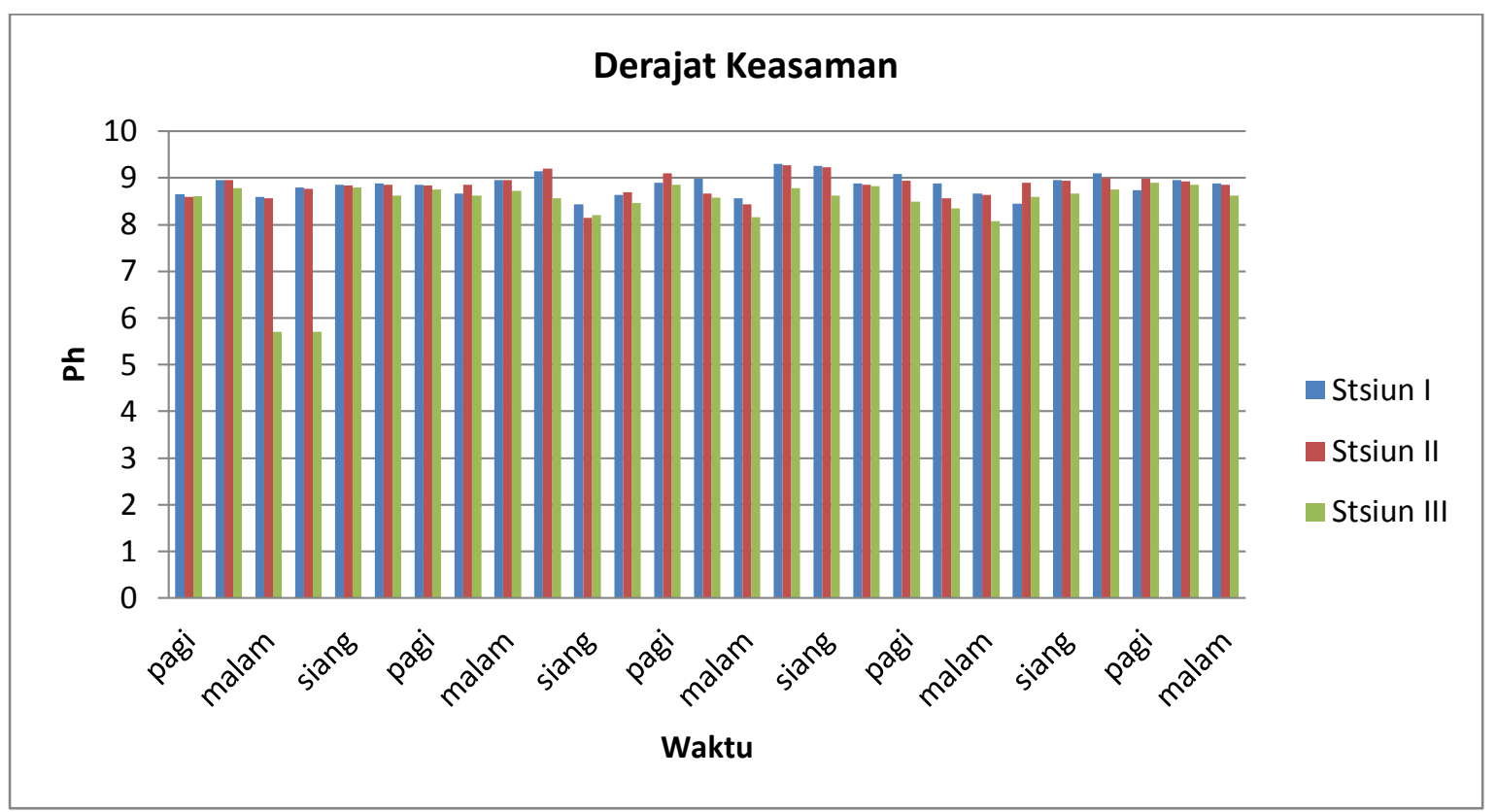

Gambar 6. Histogram derajat keasaman pada 3 stasiun pengamatan berbeda

$\mathrm{pH}$

pH hasil pengamatan di desa Paleloan untuk tiga stasiun pengamatan yang berbeda diperoleh nilai terendah sekitar 5,70 dan tertinggi sekitar 9,30. Nilai derajat keasaman untuk 5,70 merupakan hasil pengamatan pada pagi hari dan nilai 9,30 adalah hasil pengamatan pada pagi hari juga. Walaupun hasil pengamatan tersebut dilakukan pada waktu yang berbeda. (Gambar 4)

Menurut Kordi dan Tancung (2005), perairan dengan usaha budidaya yang telah

Nilai $\mathrm{pH}$ pada banyak perairan alami berkisar 4 sampai 9. Derajat keasaman lama dioperasikan cenderung memiliki $\mathrm{pH}$ yang alkalis yaitu $\mathrm{pH}$ yang tinggi. Rendahnya $\mathrm{pH}$ suatu perairan disebabkan karena kandungan asam sulfat yang terkandung pada perairan cukup tinggi. Sebaliknya untuk tingginya $\mathrm{pH}$ suatu perairan dapat disebabkan oleh tingginya kapur yang masuk ke perairan tersebut.

Disamping itu dalam Anonimous (2001b), pH yang rendah mengidikasikan bahwa keadaan perairan yang asam sedangkan $\mathrm{pH}$ yang tinggi mengidikasikan keadaan perairan yang basa.

atau $\mathrm{pH}$ air menunjukkan aktivitas ion hidrogen dalam larutan tersebut dan 
dinyatakan sebagai konsentrasi ion hidrogen (dalam mol per liter) pada suhu tertentu.
Hasil pengukuran kadar nitrgen dan phosfat pada stasiun pengamatan I, II dan III dapat ditampilkan dalam bentuk histogram seperti yang tampak pada Gambar 5a.

\section{Amoniak (NH3) dan Phosfat (PO4)}
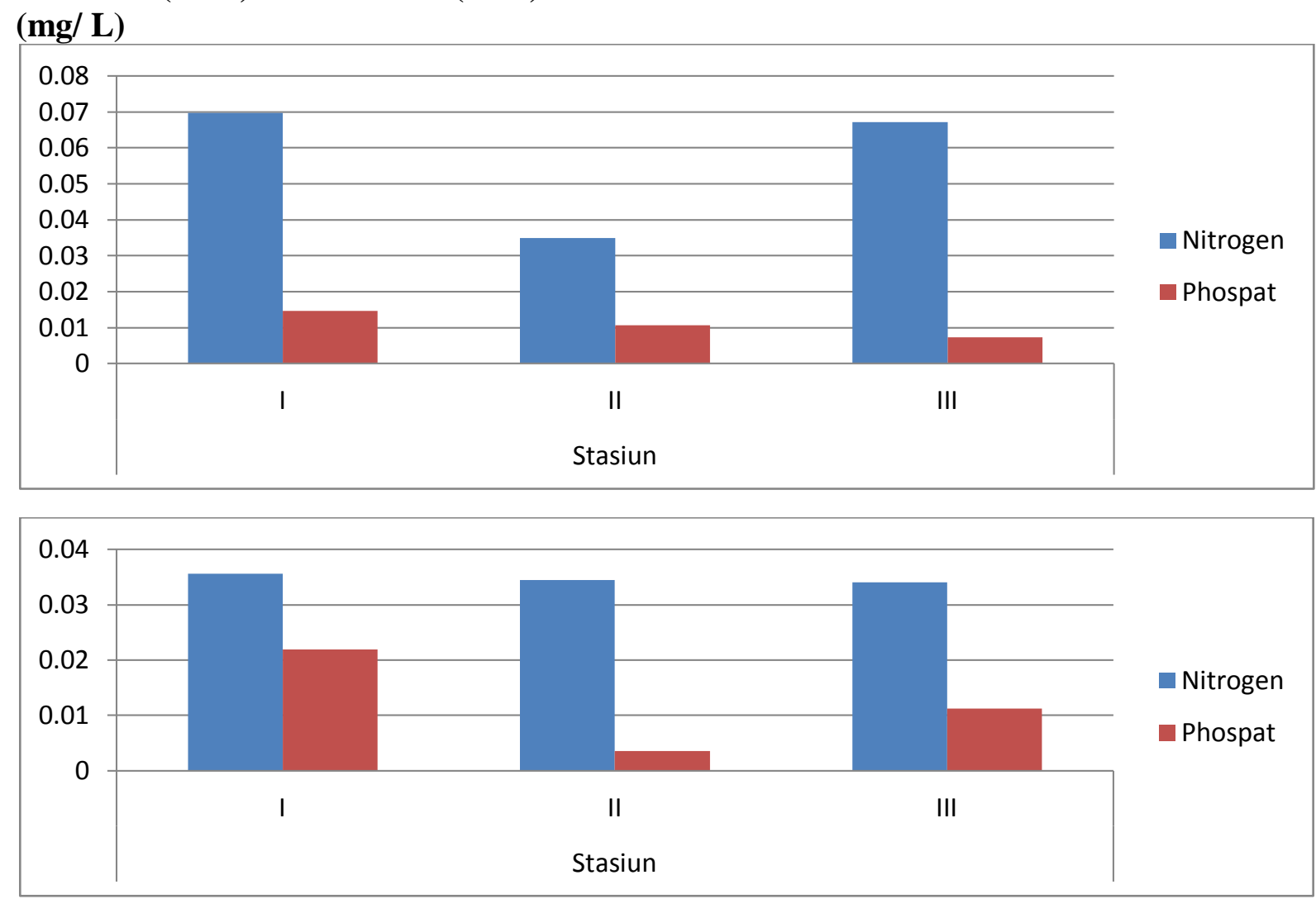

Gambar 5a. Histogram kandungan nitogen dan phosfat pada 3 stasiun pengamatan berbeda

Hasil pengukuran kadar nitrogen dan phosfat pada stasiun pengamatan I, II dan III dapat ditampilkan dalam bentuk histogram seperti yang tampak pada Gambar 5b.

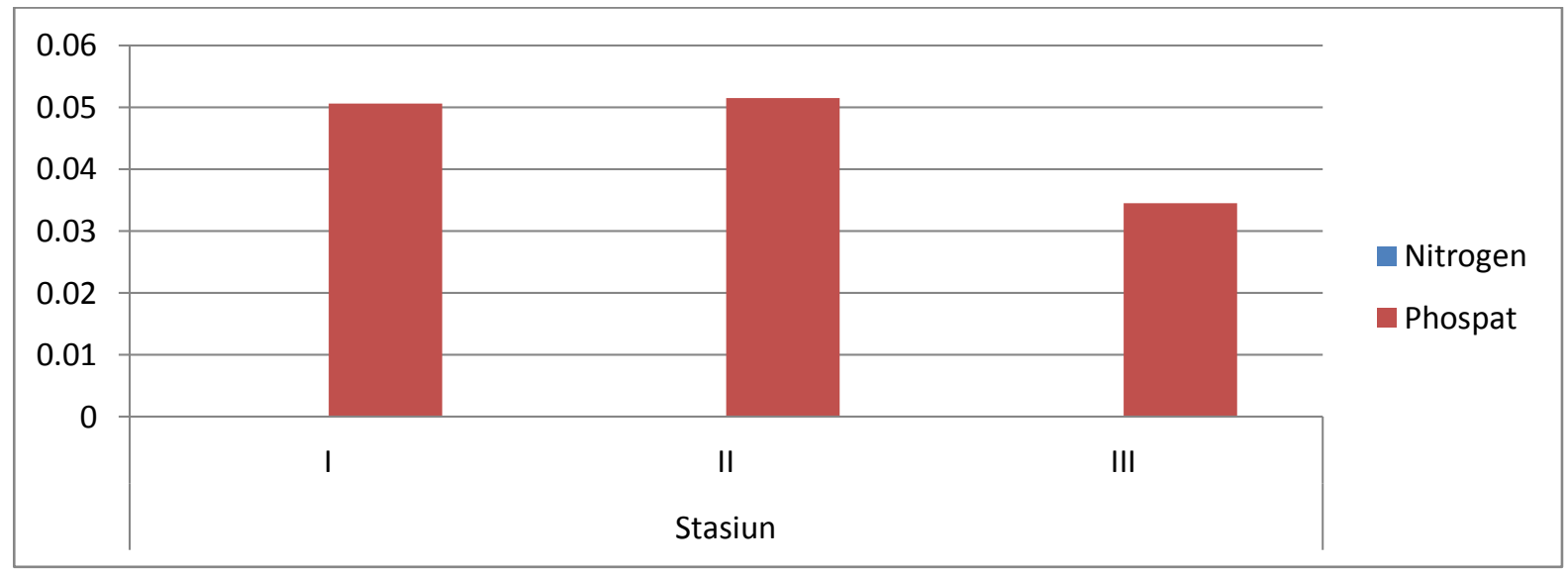




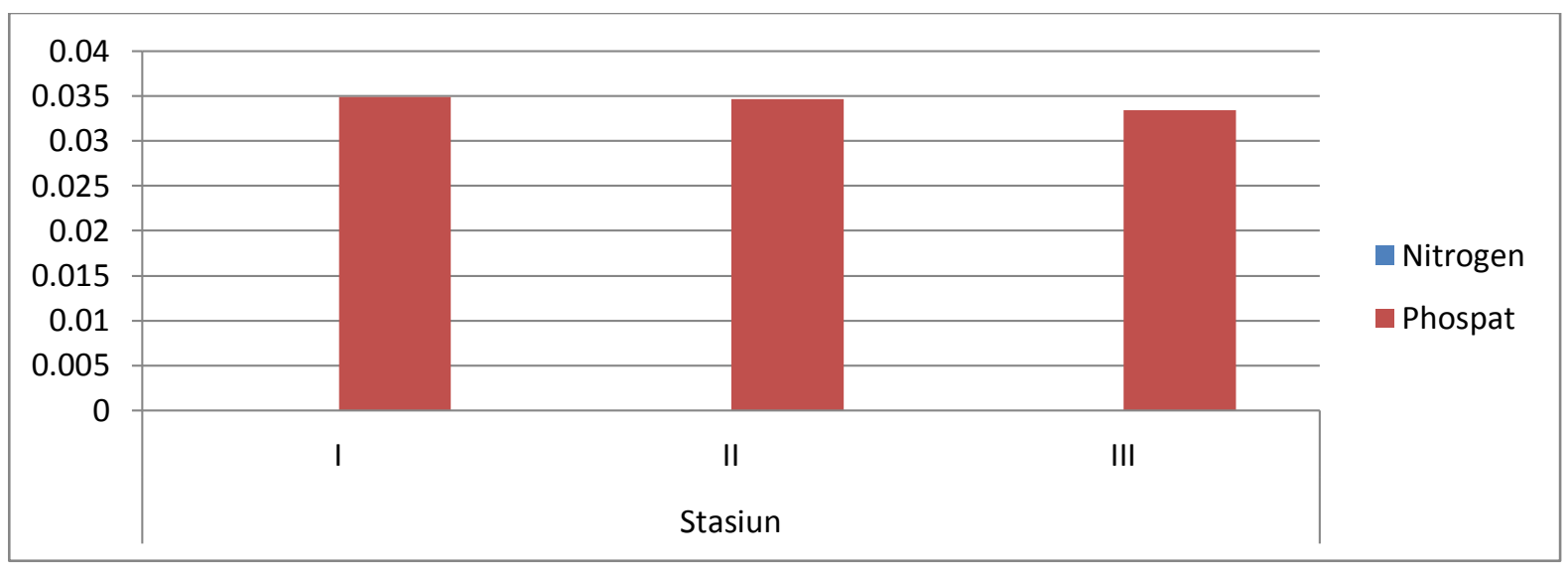

Gambar 5b. Histogram kandungan nitogen dan phosfat pada 3 stasiun pengamatan berbeda

Berdasarkan hasil pengamatan diperoleh bahwa kadar amonik terendah pada tiga stasiun yang berbeda yaitu $0,0340 \mathrm{mg} / \mathrm{L}$, dan yang tertinggi adalah $0,0697 \mathrm{mg} / \mathrm{L}$. Kadar phosfat terendah adalah $0,0036 \mathrm{mg} / \mathrm{L}$ dan tertinggi adalah $0,0219 \mathrm{mg} / \mathrm{L}$. Untuk hasil pengamatan 3 Juli 2013 diperoleh bahwa kadar amonik terendah pada tiga stasiun yang berbeda yaitu $0,0334 \mathrm{mg} / \mathrm{L}$ dan yang tertinggi adalah 0,0506mg/ L. Kadar phosfat ternedah dan tertinggi adalah $0 \mathrm{mg} / \mathrm{L}$.

Memperhatikan hasil penelitian yang dilakukan oleh Tumembouw (1999), kadar amoniak yang diperoleh berkisar 0,01 hingga $0,5 \mathrm{mg} / \mathrm{L}$. Demikian juga untuk baku mutu air menurut PP. RI No. 82 Tahun 2001 bagi perikanan, kadar atau kandungan amoniak bebas untuk ikan yang peka adalah $<0,02 \mathrm{mg} / \mathrm{L}$. Dengan demikian bila dibandingkan dengan hasil pengamatan yang diperoleh berarti bahwa kadar amoniak memiliki nilai diatas nilai kepekaan bagi ikan. Disamping itu tingginya kadar amoniak suatu perairan diduga adanya buangan limbah domestik dari penduduk sekitarnya. Sisa-sisa metabolisme atau kotoran ikan semakin banyak yang mengendap di dasar perairan tersebut sehingga terjadi kecenderungan tingginya kadar amoniak. Keadaan ini erat hubungannya dengan Boyd (1990), bahwa amoniak dalam air berasal dari kotoran organisme.
Menurut Kordi (2010), tingginya kadar amoniak suatu perairan erat kaitannya dengan tinggi suhu dan kadar derajat keasaman yang dikandungnya. Tingginya kadar amoniak suatu perairan karena terjadi pemupukan kotoran biota budidaya dan hasil kegiatan jasad renik di dalam pembusukkan bahan - bahan organik yang kaya akan nitogen atau protein.

Secara umum bahwa kadar phosfat yang diperoleh pada tiga stasiun berbeda berada pada ambang batas yang dikehendaki. Menurut Goldman dan Horne (1983), bahwa batas kandungan phosfat pada suatu perairan berkisar antara $0-0,15 \mathrm{mg} / \mathrm{L}$. Disamping itu dalam baku mutu air menurut PP. RI No. 82 tahun 2001 bahwa kandungan phosfat adalah 1 $\mathrm{mg} /$

L.

Apabila kandungan phosfat melebihi batas kebutuhan oganisme nabati, maka perairan akan menjadi amat subur (eutrofikasi).

\section{KESIMPULAN}

Berdasarkan hasil pengamatan dan pembahasan yang telah dilakukan maka pentingnya menarik beberapa kesimpulan yaitu :

(1) Parameter fisik yaitu suhu perairan berkisar 25 hingga $27^{\circ} \mathrm{C}$, kecerahan 1,5 hingga $4 \mathrm{~m}$. dan parameter kimia untuk oksigen 
terlarut 5 hingga 8, derajat keasaman atau $\mathrm{pH}$ sekitar 5 hingga 9, kadar nitrogen atau $\mathrm{NH} 40,0334$ hingga $\quad 0,0697 \mathrm{mg} / \mathrm{L}$, kadar phosfat atau PO4 0 hingga 0,0219mg/ L.

(2) Secara umum keberadaan kualitas air fisik; suhu dan kecerahan maupun kualitas kimia ; oksigen terlarut, derajat keasaman, nitrogen atau NH4 dan phosfat atau PO4 masih berada pada kondisi yang relatif baik.

(3) Pada dasarnya perairan danau Tondano yakni sekitar desa Paleloan masih dapat di gunakan usaha budidaya ikan air tawar.

\section{DAFTAR PUSTAKA}

Anonimous , 2001a. Peraturan Pemerintah Republik Indonesia Nomor 82 tahun 2001 tentang Pengelolaan Kualitas

Anonimous, 2001b. Indetifikasi Desa Sampel Perikanan Di Sulawesi Utara. Kerja Sama FPIK UNSRAT dan Dinas Perikanan dan Kelautan Pemerintah SULUT. Manado. 76 hal

Boyd. C. E., 1979. Water Quality in Warmwater Fish. Aurburn university Agricultural Experimental Station. Albama. 395 p., 1990. Water Quality In Pond For Aquakultur. Elsevier Sci. Pub. Co. Amsterdam. 482 hal.
Karu, E. 2000. Telaah Kondisi Kualitas Air di Perairan Sangihe Talaud (Teluk Lapango, Nagha dan Tahuna) suatu Studi in Situ. Skripsi Fakultas Perikanan dan Ilmu Kelautan UNSRAT, Manado. 57 hal

Kordi, M. G dan Tancung A. B., 2005. Pengelolaan Kualitas air. Penerbit Rineka Cipta. Jakarta. 208 hal.

Kordi, M. G, 2010. Budi daya Ikan Bandeng Untuk Umpan. Penerbit Akademia, Jakarta 2010. Hal 111.

Nastiti A. S., Nuroriah S., S. E. Purnamaningtyas., 2001. Dampak Budidaya Ikan Dalam Jaring Apung Terhadap Peningkatan Unsur $\mathbf{N}$ dan $\mathbf{P}$ di perairan Waduk Saguling, Cirata dan Jatiluhur. Jurnal Penelitian Perikanan. Hal 22-30.

Tumembouw, S. S., 1999. Analisis FisikoKimia Di Perairan Danau Tondano (Desa Kakas) Sekitar Tempat Pembudidayaan Ikan Dengan Sistem Jaring Apung. Rencana Kerja Penelitian. Universitas Sam Ratulangi. Fakultas Perikanan Dan Ilmu Kelautan. Manado. 21 hal.

Walandow, L. O. W. 1997. Beberapa Parameter Fisika, Kimia dan Biologi Danau Linou. Skripsi. FPIK. Unsrat. Manado. 37 hal.

Zonnelved, N. E. A. 1991. Prinsip prinsip Budidaya Ikan. Gramedia. Jakarta. 318 hal. 